\title{
Article \\ Quantifying the Influence of a Burn Event on Ammonia Concentrations Using a Machine-Learning Technique
}

\author{
Jiabao Hu ${ }^{1,2}$, Tingting Liao ${ }^{3,4, *}$, Yixuan Lü ${ }^{1,5}$, Yanjun Wang ${ }^{1}$, Yuexin He ${ }^{1}$, Weishou Shen ${ }^{2}$, Xianyu Yang ${ }^{3,4}$, \\ Dongsheng $\mathrm{Ji}^{1}$ and Yuepeng Pan $1,5,6, * \mathbb{D}$
}

check for updates

Citation: Hu, J.; Liao, T.; Lü, Y.; Wang, Y.; He, Y.; Shen, W.; Yang, X.; Ji, D.; Pan, Y. Quantifying the Influence of a Burn Event on Ammonia Concentrations Using a Machine-Learning Technique. Atmosphere 2022, 13, 170. https:// doi.org/10.3390/atmos13020170

Academic Editors: Jacek Koziel, Xuejun Liu, Baojing Gu and Lin Zhang

Received: 19 November 2021 Accepted: 18 January 2022 Published: 21 January 2022

Publisher's Note: MDPI stays neutral with regard to jurisdictional claims in published maps and institutional affiliations.

Copyright: (C) 2022 by the authors. Licensee MDPI, Basel, Switzerland. This article is an open access article distributed under the terms and conditions of the Creative Commons Attribution (CC BY) license (https:// creativecommons.org/licenses/by/ $4.0 /)$.
1 State Key Laboratory of Atmospheric Boundary Layer Physics and Atmospheric Chemistry (LAPC), Institute of Atmospheric Physics, Chinese Academy of Sciences, Beijing 100029, China; hujiabao@nuist.edu.cn (J.H.); lvyixuan20@mails.ucas.ac.cn (Y.L.); 201842859@mail.sdu.edu.cn (Y.W.); heyuexin15@mails.ucas.ac.cn (Y.H.); jds@dq.cern.ac.cn (D.J.)

2 Collaborative Innovation Centre of Atmospheric Environment and Equipment Technology, Jiangsu Key Laboratory of Atmospheric Environment Monitoring and Pollution Control, School of Environmental Science and Engineering, Nanjing University of Information Science \& Technology, Nanjing 210044, China; wsshen@nuist.edu.cn

3 The Plateau Atmosphere and Environment Key Laboratory of Sichuan Province, School of Atmospheric Science, Chengdu University of Information Technology, Chengdu 610225, China; xyang@cuit.edu.cn

4 Chengdu Plain Urban Meteorology and Environment Observation and Research Station of Sichuan Province, Chengdu 610225, China

5 College of Earth and Planetary Sciences, University of Chinese Academy of Sciences, Beijing 100049, China

6 Artificial Intelligence Research Center for Atmospheric Science, Beijing 100029, China

* Correspondence: ltt2014@cuit.edu.cn (T.L.); panyuepeng@mail.iap.ac.cn (Y.P.)

\begin{abstract}
Although combustion is considered a common source of ammonia $\left(\mathrm{NH}_{3}\right)$ in the atmosphere, field measurements quantifying such emissions of $\mathrm{NH}_{3}$ are still lacking. In this study, online measurements of $\mathrm{NH}_{3}$ were performed by a cavity ring-down spectrometer, in the cold season at a rural site in Xianghe on the North China Plain. We found that the $\mathrm{NH}_{3}$ concentrations were mostly below 65 ppb during the study period. However, from 18 to 21 November 2017, a close burn event $(\sim 100 \mathrm{~m})$ increased the $\mathrm{NH}_{3}$ concentrations to $145.6 \pm 139.9 \mathrm{ppb}$. Using a machine-learning technique, we quantified that this burn event caused a significant increase in $\mathrm{NH}_{3}$ concentrations by $411 \%$, compared with the scenario without the burn event. In addition, the ratio of $\Delta \mathrm{NH}_{3} / \Delta \mathrm{CO}$ during the burn period was 0.016 , which fell in the range of biomass burning. Future investigations are needed to evaluate the impacts of the $\mathrm{NH}_{3}$ combustion sources on air quality, ecosystems, and climate in the context of increasing burn events worldwide.
\end{abstract}

Keywords: random forest model; ammonia; burn events; combustion sources; China

\section{Introduction}

As an important alkaline gas in the atmosphere, atmospheric ammonia $\left(\mathrm{NH}_{3}\right)$ has a crucial influence on atmospheric chemistry and the nitrogen cycle [1,2]. It can react with sulfuric acid $\left(\mathrm{H}_{2} \mathrm{SO}_{4}\right)$ and nitric acid $\left(\mathrm{HNO}_{3}\right)$, and enhance the formation of secondary inorganic aerosols (SIAs) [3]. Additionally, $\mathrm{NH}_{3}$ can enhance the yield of secondary organic aerosols (SOAs) through aqueous chemistry [4]. These particulate SIAs and SOAs in the air decrease visibility, damage human health, and affect the climate [5-9]. After deposition, $\mathrm{NH}_{3}$ can directly or indirectly affect terrestrial and aquatic ecosystems, such as soil acidification, water eutrophication, and reduction in biodiversity [10-12]. Thus, identifying and quantifying the sources of $\mathrm{NH}_{3}$ is essential to understanding its vital role in atmospheric chemistry and reducing its negative impacts on the ecosystem and climate.

Although livestock waste and nitrogen fertilization are considered the most important sources of $\mathrm{NH}_{3}$ emissions on a global or regional scale $[13,14], \mathrm{NH}_{3}$ is also emitted into 
the atmosphere during the fuel combustion process through pyrolysis [15]. Biomass burning, such as forest fires, plays a critical role in $\mathrm{NH}_{3}$ emissions in rural areas. For example, 1.4-8.2 and 0.7-2.6 Tg of $\mathrm{NH}_{3}$ were emitted from forest fires in Indonesia in autumn in 2015, and Russia in July-August 2010, respectively [16,17], and $0.12 \mathrm{Mt}$ of $\mathrm{NH}_{3}$ was emitted from agricultural crop residue burning in India from 2008 to 2009 [18]. In urban areas, the nitrogen isotopic approach indicates that $\mathrm{NH}_{3}$ originated primarily from combustion sources, including coal combustion, $\mathrm{NH}_{3}$ slip from power plants, and vehicle exhausts [19-21]. A high-resolution global inventory revealed that $\mathrm{NH}_{3}$ emissions from combustion sources continued to increase from 1960 to 2013 [22]. In China, an average of 8182 forest fires occurred from 1987 to 2007 [23]. The elevated fire frequencies were partially due to climate change [24]. Thus, the impact of combustion sources on $\mathrm{NH}_{3}$ concentrations and related consequences needs further attention.

China is a global hotspot of atmospheric $\mathrm{NH}_{3}$ emissions, with an annual increasing rate of $1.9 \%$ [25]. Notably, the North China Plain (NCP) is confirmed to be the largest region with high surface concentrations, and the highest emissions in China [26]. Despite the pollution reduction actions implemented since 2013, severe haze pollution events still occur in the cold season in this region. For example, the highest $\mathrm{PM}_{2.5}$ concentration reached approximately $250 \mu \mathrm{g} / \mathrm{m}^{3}$ in winter in 2020 [27], and it was dominated by sulfate-nitrateammonium (SNA), especially nitrate aerosols [28]. Recent studies have suggested that $\mathrm{NH}_{3}$ plays an important role in determining nitrate concentrations [29,30]. Therefore, it is necessary to observe the concentrations of $\mathrm{NH}_{3}$ and investigate its emission sources in this region.

In this study, we performed online measurements of $\mathrm{NH}_{3}$ in the cold season in Xianghe, a rural site in NCP. During the observation campaign, we detected an unexpected burn event that had a significant influence on the $\mathrm{NH}_{3}$ concentrations. Finally, we attempted to combine a novel machine-learning technique based on the random forest (RF) algorithm, to quantify the impact of burn events. Such an understanding could be beneficial for controlling $\mathrm{NH}_{3}$ emissions and further improving air quality in the future.

\section{Data and Methods}

\subsection{Site Description}

Since 2017, online measurements of $\mathrm{NH}_{3}$ concentrations have been performed in Xianghe, $\mathrm{NCP}\left(39.75^{\circ} \mathrm{N}, 116.96^{\circ} \mathrm{E}\right)$ (Figure 1$)$. The site is surrounded by residential areas that lack tall buildings and obvious industrial emission sources. Based on its location in the northern part of the NCP between Beijing $(\sim 45 \mathrm{~km})$ and Tianjin $(\sim 70 \mathrm{~km})$, the instruments at the site can detect pollutants of urban, rural, background or mixed origins, reflecting the complex changes in $\mathrm{NH}_{3}$ in the NCP.

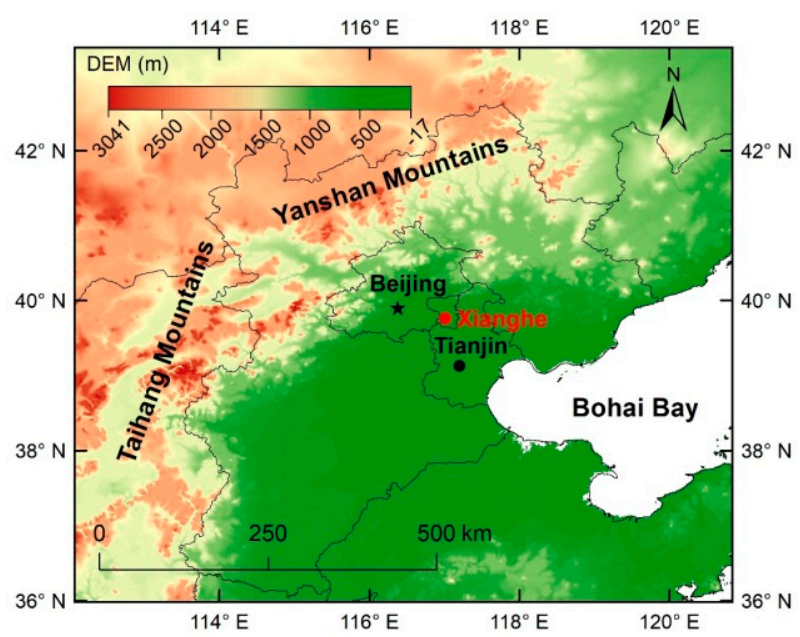

Figure 1. Location of the $\mathrm{NH}_{3}$ observation site in Xianghe. 


\subsection{Data Sources}

\subsubsection{Measurements of $\mathrm{NH}_{3}$}

Hourly concentrations of $\mathrm{NH}_{3}$ were measured at a high temporal resolution of $1 \mathrm{~Hz}$ online, using a standard cavity ring-down spectrometer (CRDS) (G2103, Picarro Inc., Santa Clara, CA, USA). CRDS is a direct absorption technique that uses pulsed or continuous light sources and has a significantly higher sensitivity than conventional spectrometers [31]. In CRDS, two high reflectivity mirrors are used in the optical cavity to increase the absorption optical path length, thereby enhancing the contrast of the absorption signal of $\mathrm{NH}_{3}$. The CRDS setting measures how long it takes for the light to drop to a certain percentage of its original intensity, and the "ring-down time" is used to calculate the concentration of $\mathrm{NH}_{3}$ in the cavity [32].

To prevent water vapor from affecting the $\mathrm{NH}_{3}$ spectrum, the manufacturer has incorporated a correction procedure for the reported $\mathrm{NH}_{3}$ values [33]. In addition, to reduce the adsorption of $\mathrm{NH}_{3}$, the Teflon tubing was insulated and warmed with heating tape $\left(\sim 45.7^{\circ} \mathrm{C}\right)$. Meanwhile, a filter was installed at the front of the inlet to induce ambient air flow. According to the air conditions, the filter was replaced every 2 weeks to 1 month. The instrument was placed in an air-conditioned cabin laboratory; more detailed descriptions are documented elsewhere [34].

\subsubsection{Other Supporting Data}

Air pollutants and meteorological data are also used in this study. The hourly concentrations of $\mathrm{SO}_{2}, \mathrm{NO}_{\mathrm{x}}, \mathrm{CO}$, and $\mathrm{PM}_{2.5}$ were measured at the same height as $\mathrm{NH}_{3}$. Meteorological parameters, including temperature $(\mathrm{T})$, relative humidity $(\mathrm{RH})$, wind speed (WS), and wind direction (WD), were obtained from the China Meteorological Administration (http:/ / data.cma.cn (accessed on 14 October 2021)).

\subsubsection{Burn Event}

During the observation campaign, a burn event occurred from 18 to 21 November, 2017. This burn event was caused by the combustion of garbage in the nearby residential area, which was approximately $100 \mathrm{~m}$ away from the observation site. The burned material was complex and included discarded paper, kitchen waste, crop residues, weeds, branches, and leaves.

\subsection{RF Models}

The temporal variations in $\mathrm{NH}_{3}$ in this study demonstrated a cycle ranging from 4 to 7 days. These strong cycles are regional in nature and controlled by the passage of cold fronts [35]. This unique temporal feature indicated that the results presented are reproducible on a regular basis, and applicable for the RF model in predicting $\mathrm{NH}_{3}$ dynamics with meteorological conditions.

In this study, we used a machine-learning technique to quantify the influence of burn events on $\mathrm{NH}_{3}$ concentrations. First, we established a model (RF1) with observed $\mathrm{NH}_{3}$ concentrations as the dependent variable, and predictors (meteorological parameters, time predictors, and regional transport parameters) as the independent variables (Table 1). RF1 was trained on datasets during the nonburning period (8-17 and 22-30 November 2017). The training set accounted for $80 \%$ of data, and the testing set included the remaining $20 \%$. On the basis of RF1, a series of models (RF2-RF11) were established, according to the relative importance of the predictor variables for eliminating or adding some predictors (Table S1). A detailed evaluation of all the established models is provided in Table S2, including the coefficients of determination $\left(\mathrm{R}^{2}\right)$, the fraction of predictions within a factor of 2 (FAC2), mean bias, normalized mean bias, root-mean-square error (RMSE), and Pearson correlation coefficient (PCC). The performance of RF5 was considered the best due to its higher $\mathrm{R}^{2}$ and lower RMSE.

The RF models were developed using the rmweather $\mathrm{R}$ package. However, unlike previous studies, we further adjusted two important parameters of RF5, namely, the number of trees (ntree) and the number of variables split in each node (mtry). Mtry values from 1 to 
8 with an interval of 1 , and ntree values from 50 to 500 with an interval of 50, were selected. As shown in Figure S1, when ntree was 300 and mtry was 5, the simulation effect of the model was best, as indicated by the higher $\mathrm{R}^{2}$ value and lower prediction error (MSE).

Table 1. All possible predictors for the RF models in this study.

\begin{tabular}{lll}
\hline Codes & Prediction Variables & Units \\
\hline Meteorological parameters & & \\
\hline $\mathrm{T}$ & Air Temperature & ${ }^{\circ} \mathrm{C}$ \\
$\mathrm{WS}$ & Wind speed & $\mathrm{m} / \mathrm{s}$ \\
$\mathrm{WD}$ & Wind direction & degree \\
Pressure & Atmospheric pressure & $\mathrm{hPa}$ \\
$\mathrm{RH}$ & Relative humidity & $\%$ \\
\hline Time parameters & & \\
\hline day_Julian & Date of the year $(1-366)$ & $\mathrm{n} / \mathrm{a}$ \\
weekday & Day of the week $(1-7)$ & $\mathrm{n} / \mathrm{a}$ \\
hour & Hour of the day $(0-23)$ & $\mathrm{n} / \mathrm{a}$ \\
\hline Air pollutants & & \\
\hline $\mathrm{PM}_{2.5}$ & Particulate matter & $\mu \mathrm{g} / \mathrm{m}^{3}$ \\
$\mathrm{NO}_{\mathrm{x}}$ & Nitrogen oxides & $\mu \mathrm{g} / \mathrm{m}^{3}$ \\
$\mathrm{NO}_{2}$ & Nitrogen dioxide & $\mu \mathrm{g} / \mathrm{m}^{3}$ \\
$\mathrm{SO}_{2}$ & Sulfur dioxide & $\mu \mathrm{g} / \mathrm{m}^{3}$ \\
$\mathrm{CO}$ & Carbon monoxide & $\mathrm{ppb}$ \\
$\mathrm{NO}^{\mathrm{R} O}$ & Nitrogen monoxide & $\mu \mathrm{g} / \mathrm{m}^{3}$ \\
\hline $\mathrm{Regional} \mathrm{transport} \mathrm{parameter}$ & & \\
\hline cluster & Back trajectory cluster & $\mathrm{n} / \mathrm{a}$ \\
\hline
\end{tabular}

After the RF model was adjusted and optimized, the testing datasets were randomly selected to assess the correlation between the observed and predicted concentrations (Figure S2), to ensure that this model could make better predictions. Finally, we used this model to predict $\mathrm{NH}_{3}$ concentrations under the assumption of no burn events. To evaluate the impact of the burn events (18-21 November 2017) on $\mathrm{NH}_{3}$ concentrations, relative changes $(R)$ between the observed concentrations $\left(C_{\text {observed }}\right)$ and predicted concentrations $\left(C_{\text {predicted }}\right)$ for $\mathrm{NH}_{3}$ were defined using the following equation:

$$
R=\frac{C_{\text {observed }}-C_{\text {predicted }}}{C_{\text {predicted }}} \times 100 \%
$$

\section{Results and Discussion}

\subsection{Changes in Observed Concentrations of $\mathrm{NH}_{3}$}

Hourly concentrations of $\mathrm{NH}_{3}$ were selected from 8 to 30 November 2017 in this study, and their temporal variations are shown in Figure 2. We found that the $\mathrm{NH}_{3}$ concentrations were mostly below $65 \mathrm{ppb}$ during the study period, with the exception of 18-21 November, when a burn event occurred. Therefore, in the following sections, we have separated the dataset into two periods, i.e., the burning period (18-21 November 2017) and the nonburning period (8-17 and 22-30 November 2017).

During the nonburning period, the $\mathrm{NH}_{3}$ concentrations in Xianghe ranged from 1.9 to $154.3 \mathrm{ppb}$, with a mean value of $25.4 \pm 16.9 \mathrm{ppb}$. The $\mathrm{NH}_{3}$ concentrations in this study were comparable to the urban observations (28.5 $\pm 11.6 \mathrm{ppb})$ in autumn in Beijing [36]. Moreover, the average $\mathrm{NH}_{3}$ level measured in Xianghe was generally similar to observations in India $(24.6 \pm 5.0 \mathrm{ppb})$ [37], but much higher than those in Europe (1.2 ppb) and the United States (2.4 ppb) in autumn [10,38].

After the start of the burn event, the observed concentrations of $\mathrm{NH}_{3}$ significantly increased, with the highest value exceeding $600 \mathrm{ppb}$. In addition, three concentration spikes 
occurred: at 7:00, 18 November (281.6 ppb); 2:00, 19 November (547.1 ppb); and 10:00, 20 November (601.4 ppb). During the burning period, the average $\mathrm{NH}_{3}$ concentration was $145.6 \pm 139.9 \mathrm{ppb}$, which is five times that in a previous report $(26.6 \pm 13.9 \mathrm{ppb})$ at the Xianghe site in the cold season [39].

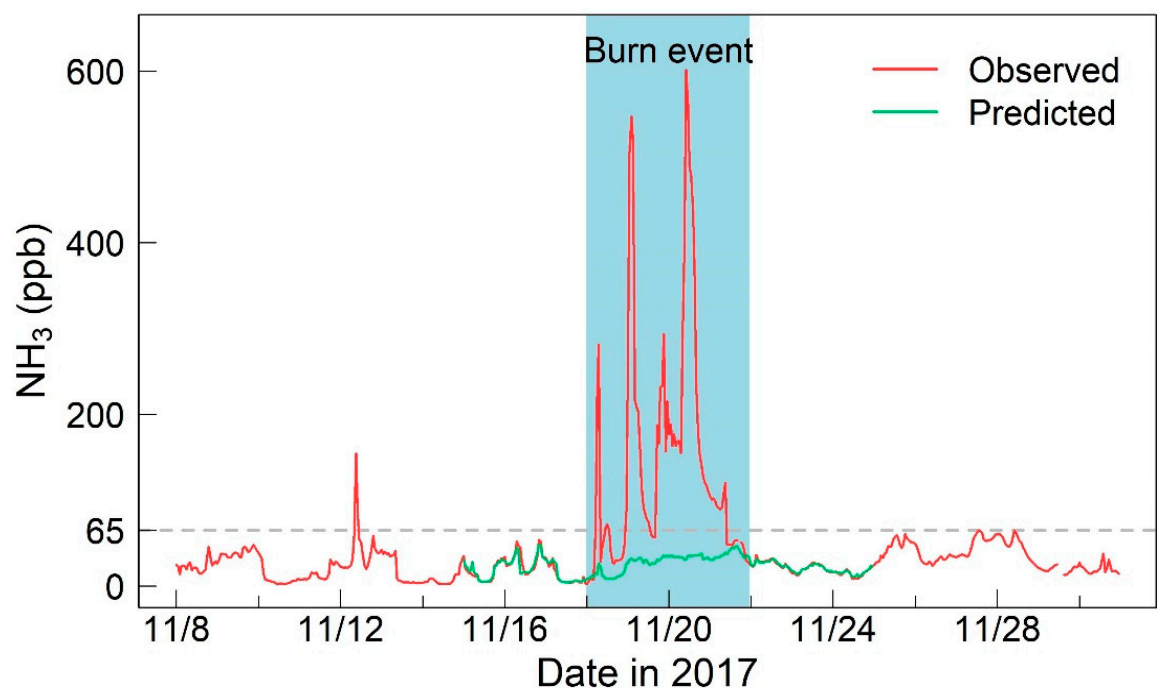

Figure 2. Temporal variation in hourly concentrations of $\mathrm{NH}_{3}$. The gray line indicates an $\mathrm{NH}_{3}$ concentration of $65 \mathrm{ppb}$. The blue shaded area represents the burning period, and the non-shaded area represents the nonburning period.

In addition to $\mathrm{NH}_{3}$, the concentrations of other air pollutants also significantly increased during the burning period, e.g., by $209.7 \%, 84.3 \%, 69.1 \%$, and $79.8 \%$ for $\mathrm{PM}_{2.5}, \mathrm{SO}_{2}$, $\mathrm{NO}_{x}$, and $\mathrm{CO}$, respectively (Figure S3). These air pollutants had a positive correlation with $\mathrm{NH}_{3}$ during the burning period, especially $\mathrm{CO}\left(\mathrm{R}^{2}=0.74, p<0.01\right)$ and $\mathrm{NO}_{\mathrm{x}}\left(\mathrm{R}^{2}=0.72\right.$, $p<0.01)$. However, their positive correlation was not significant in the nonburning period (Table S3). These results all indicated the potential influence of combustion sources on air quality. In addition, the intensity of combustion was closely related to weather conditions [40]. In our study, the $\mathrm{NH}_{3}$ concentrations were higher during the burning period when the air mass originated from the northwest, and had a higher RH (56.2 $\pm 26.3 \%)$ and lower $\mathrm{T}\left(-1.1 \pm 5^{\circ} \mathrm{C}\right)$ and WS $\left(1.6 \pm 1.5 \mathrm{~m} \mathrm{~s}^{-1}\right)$ (Figure S4). To quantify the impact of the burn events on $\mathrm{NH}_{3}$, we predicted $\mathrm{NH}_{3}$ concentrations without burn events using a machine-learning technique in the next section.

\subsection{Changes in Predicted Concentrations of $\mathrm{NH}_{3}$}

We first established a model (RF5) to predict the $\mathrm{NH}_{3}$ concentrations assuming that no burn event occurred from 18 to 21 November 2017. The predicted results are shown in Figure 2, with all predicted concentrations lower than $65 \mathrm{ppb}$. In addition, the temporal variation in predicted $\mathrm{NH}_{3}$ concentrations was basically similar to its observed value in the nonburning period. This finding indicates that the concentrations and temporal pattern of $\mathrm{NH}_{3}$ will not change significantly if there is no burn event.

The difference between the predicted and observed concentrations of $\mathrm{NH}_{3}$ allows us to quantify the impacts of burn events on $\mathrm{NH}_{3}$ emissions. As shown in Figure 3 and Table S4, remarkable differences were not found between the observed and predicted concentrations of $\mathrm{NH}_{3}$ before the burn event, indicating that our model captured the variations in $\mathrm{NH}_{3}$ concentrations well. However, the observed concentration of $\mathrm{NH}_{3}$ increased drastically compared with the predicted value during the burning period, with increased ratios of $336.9 \%, 561.1 \%$, and $652.2 \%$ in the first three days of the burn event. At the end of the burning period and with the resumption of "normal emissions", the predicted values were consistent with the observations after 22 November. Overall, the observed and predicted concentrations of $\mathrm{NH}_{3}$ during the burning period were $145.6 \pm 139.9$ and $28.5 \pm 10.4 \mathrm{ppb}$, 
respectively, resulting in an increase of $411 \%$. These results indicated that the combustion source is an important factor of $\mathrm{NH}_{3}$ emissions.

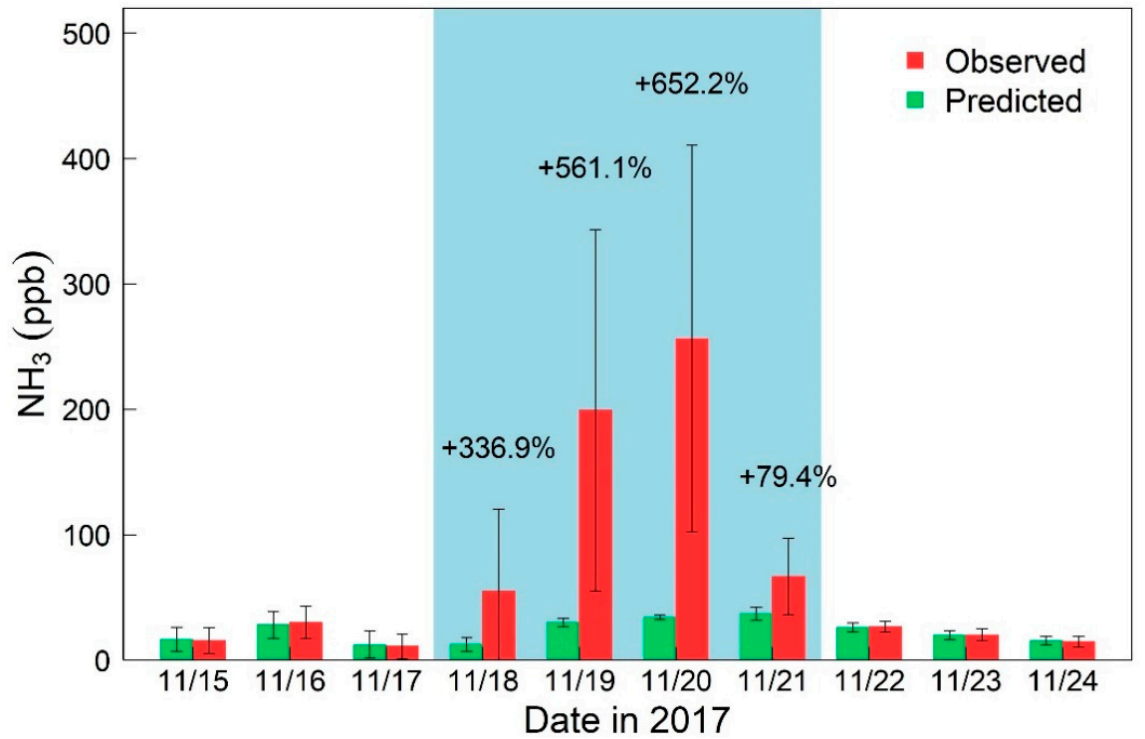

Figure 3. Observed and predicted concentrations of $\mathrm{NH}_{3}$ before, during and after the burning period at the Xianghe site. Percentages on bars indicate relative changes $(R)$ between the observed and predicted concentrations.

\subsection{Dominant Source of $\mathrm{NH}_{3}$ during the Burn Event}

Although the overall impacts of the burn event on $\mathrm{NH}_{3}$ concentrations were identified in the above sections, the potential dominant source contributing to the substantial increase in $\mathrm{NH}_{3}$ was still unclear. To address this concern, we further investigated the relationship between $\mathrm{NH}_{3}$ and other air pollutants.

As shown in Figure 4, we found that the ratio of $\mathrm{NH}_{3}$ to other air pollutants significantly increased after the burn event occurred. Compared with those before burn events, the ratio of $\mathrm{NH}_{3} / \mathrm{PM}_{2.5}, \mathrm{NH}_{3} / \mathrm{SO}_{2}, \mathrm{NH}_{3} / \mathrm{NO}_{\mathrm{x}}$, and $\mathrm{NH}_{3} / \mathrm{CO}$ increased by actor of 1.6 , $2.5,3.0$, and 5.4 during the burning period, respectively (Table S5). This finding indicated a dramatic change of $\mathrm{CO}$ during the burn event. Thus, $\mathrm{CO}$ was selected as a tracer of fire [41]. Then, the emission ratio (ER) was defined as $\Delta \mathrm{NH}_{3} / \Delta \mathrm{CO}$ in our study $[17,42]$, where $\Delta \mathrm{NH}_{3}$ and $\Delta \mathrm{CO}$ represented the difference in the corresponding concentrations of $\mathrm{NH}_{3}$ and $\mathrm{CO}$ before and during the burn event. In this study, the calculated $\Delta \mathrm{NH}_{3} / \Delta C \mathrm{O}$ value was 0.016 , which was consistent with the characteristics of biomass burning (Table 2). Therefore, the dominant source emitting substantial $\mathrm{NH}_{3}$ might be biomass burning in this burn event. Future control measures on $\mathrm{NH}_{3}$ emissions should pay more attention to potential contributions from biomass burning.

Table 2. Summary of the $\mathrm{NH}_{3}$ concentration and its emission ratio $\left(\mathrm{ER}=\Delta \mathrm{NH}_{3} / \Delta \mathrm{CO}\right)$ in different burn events.

\begin{tabular}{|c|c|c|c|c|c|}
\hline \multirow{2}{*}{ Focus Region } & \multirow{2}{*}{ Event } & \multicolumn{2}{|c|}{$\mathrm{NH}_{3}(\mathrm{ppb})$} & \multirow{2}{*}{$\mathrm{ER}(\mathrm{ppb} / \mathrm{ppb})$} & \multirow{2}{*}{ Reference } \\
\hline & & Range & Average & & \\
\hline Xianghe, China & Biomass burning & $2.4-601.4$ & $145.6 \pm 139.9$ & 0.016 & this study \\
\hline Shenyang, China & Vehicular exhaust & $61.8-248.3$ & $152.9 \pm 55.6$ & - & [43] \\
\hline Canada and U.S. & Forest fire & $7-130$ & - & 0.012 & [44] \\
\hline Yucatan, Mexico & Biomass burning & - & - & 0.022 & [45] \\
\hline California, U.S. & Biomass burning & - & - & 0.019 & [46] \\
\hline Colorado, U.S. & Wildfires & $<150$ & - & 0.027 & [47] \\
\hline the Flint Hills, U.S. & Grassland fire & - & 95 & - & [48] \\
\hline Western U.S. & Wildfires & $>400$ & - & - & [49] \\
\hline
\end{tabular}



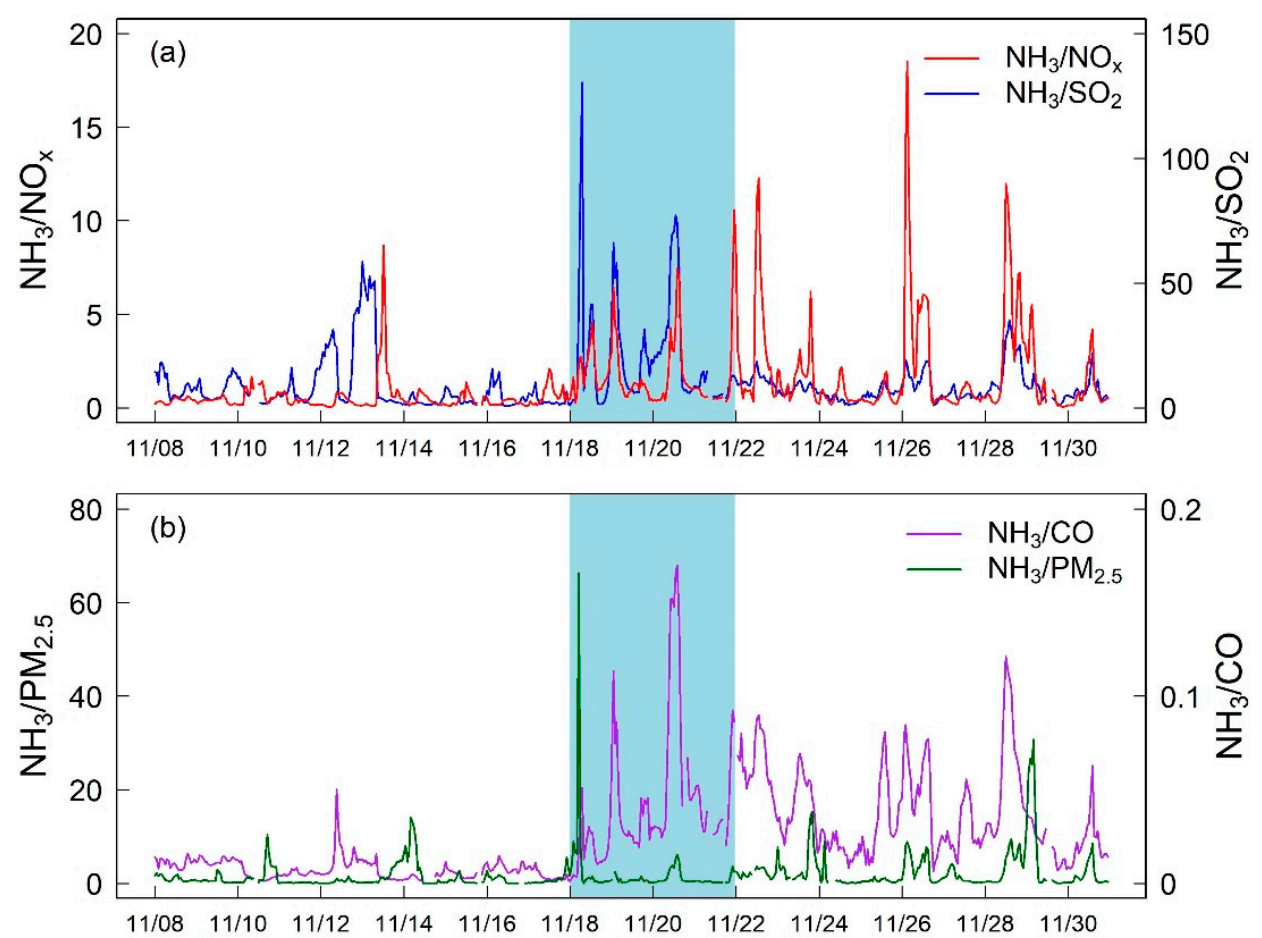

Figure 4. Temporal variation in the ratio of $\mathrm{NH}_{3}$ relative to $\mathrm{NO}_{X}, \mathrm{SO}_{2}(\mathbf{a}), \mathrm{CO}$ and $\mathrm{PM}_{2.5}(\mathbf{b})$.

\section{Conclusions}

In this study, the $\mathrm{NH}_{3}$ concentrations were measured by the CRDS technique in the cold season at a rural site in the NCP. The hourly $\mathrm{NH}_{3}$ concentrations were mostly below $65 \mathrm{ppb}$ during the study period. However, an unexpected burn event caused a significant increase in $\mathrm{NH}_{3}$ concentration from 18 to 21 November 2017, with peak values exceeding $600 \mathrm{ppb}$. With the aid of a machine-learning technique, we found that the burn event could cause a $411 \%$ increase in the $\mathrm{NH}_{3}$ concentration. Notably, the $\Delta \mathrm{NH}_{3} / \Delta \mathrm{CO}$ ratio was 0.016 during the burning period, indicating that biomass burning might be the dominant emission source. Due to the increasing occurrence of burn events worldwide, the impacts of the combustion sources of $\mathrm{NH}_{3}$ on air quality, ecosystems, and climate need to be further explored.

Supplementary Materials: The following are available online at https:/ / www.mdpi.com/article/ 10.3390/atmos13020170/s1: Figure S1: Influence of different ntree and mtry values on RF model; Figure S2: Performance of the $\mathrm{RF}$ model in predicting the $\mathrm{NH}_{3}$ concentrations; Figure S3: Temporal variation of hourly concentrations of $\mathrm{PM}_{2.5}, \mathrm{SO}_{2}, \mathrm{NO}_{\mathrm{x}}$, and $\mathrm{CO}$; Figure S4: Hourly variation of meteorological parameters; Table S1: Summary of $11 \mathrm{RF}$ models and their predictors in this study; Table S2: Model validation in $11 \mathrm{RF}$ models in this study; Table S3: Correlation matrix of $\mathrm{NH}_{3}$, other air pollutants and meteorological parameters during the burning period; Table S4: Observed and predicted concentrations of $\mathrm{NH}_{3}$ at the Xianghe site during the burning period; Table S5: Range and average of the ratio between $\mathrm{NH}_{3}$ and other air pollutants before and during the burn event.

Author Contributions: Conceptualization, Y.P.; methodology, J.H.; software, J.H., Y.W. and Y.H.; validation, J.H.; formal analysis, J.H.; investigation, J.H. and Y.L.; resources, Y.P., D.J. and T.L.; data curation, J.H.; writing—original draft preparation, J.H.; writing—review and editing, Y.P. and W.S.; visualization, J.H.; supervision, Y.P. and W.S.; project administration, Y.P. and X.Y.; funding acquisition, Y.P., T.L. and X.Y. All authors have read and agreed to the published version of the manuscript.

Funding: This research was funded by the National Natural Science Foundation of China [grant number 42077204] and the Open Research Fund Program of Plateau Atmosphere and Environment Key Laboratory of Sichuan Province (Project PAEKL-2020-C3).

Institutional Review Board Statement: Not applicable. 
Informed Consent Statement: Not applicable.

Data Availability Statement: The data presented in this study are available on reasonable request from the corresponding author.

Conflicts of Interest: The authors declare no conflict of interest.

\section{References}

1. Zhao, Y.; Zhang, L.; Pan, Y.; Wang, Y.; Paulot, F.; Henze, D.K. Atmospheric nitrogen deposition to the northwestern Pacific: Seasonal variation and source attribution. Atmos. Chem. Phys. 2015, 15, 10905-10924. [CrossRef]

2. Wen, Z.; Xu, W.; Li, Q.; Han, M.; Tang, A.; Zhang, Y.; Luo, X.; Shen, J.; Wang, W.; Li, K.; et al. Changes of nitrogen deposition in China from 1980 to 2018. Environ. Int. 2020, 144, 106022. [CrossRef] [PubMed]

3. Pan, Y.; Tian, S.; Liu, D.; Fang, Y.; Zhu, X.; Zhang, Q.; Zheng, B.; Michalski, G.; Wang, Y. Fossil fuel combustion-related emissions dominate atmospheric ammonia sources during severe haze episodes: Evidence from ${ }^{15} \mathrm{~N}$-stable isotope in size-resolved aerosol ammonium. Environ. Sci. Technol. 2016, 50, 8049-8056. [CrossRef]

4. Fu, X.; Wang, S.; Xing, J.; Zhang, X.; Wang, T.; Hao, J. Increasing ammonia concentrations reduce the effectiveness of particle pollution control achieved via $\mathrm{SO}_{2}$ and $\mathrm{NO}_{x}$ emissions reduction in east China. Environ. Sci. Technol. Lett. 2017, 4, 221-227. [CrossRef]

5. Chen, W.; Tong, D.Q.; Dan, M.; Zhang, S.; Zhang, X.; Pan, Y. Typical atmospheric haze during crop harvest season in northeastern China: A case in the Changchun region. J. Environ. Sci. 2017, 54, 101-113. [CrossRef] [PubMed]

6. Xin, J.; Wang, Y.; Wang, L.; Tang, G.; Sun, Y.; Pan, Y.; Ji, D. Reductions of PM 2.5 in Beijing-Tianjin-Hebei urban agglomerations during the 2008 Olympic Games. Adv. Atmos. Sci. 2012, 29, 1330-1342. [CrossRef]

7. Li, W.; Liu, X.; Zhang, Y.; Sun, K.; Wu, Y.; Xue, R.; Zeng, L.; Qu, Y.; An, J. Characteristics and formation mechanism of regional haze episodes in the Pearl River Delta of China. J. Environ. Sci. 2018, 63, 236-249. [CrossRef]

8. Wu, J.; Wu, Y.; Tian, Y.; Wu, Y.; Wang, M.; Wang, X.; Wang, Z.; Hu, Y. Association between ambient fine particulate matter and adult hospital admissions for pneumonia in Beijing, China. Atmos. Environ. 2020, 231, 117497. [CrossRef]

9. Zhu, L.; Henze, D.K.; Bash, J.O.; Cady-Pereira, K.E.; Shephard, M.W.; Luo, M.; Capps, S.L. Sources and impacts of atmospheric $\mathrm{NH}_{3}$ : Current understanding and frontiers for modeling, measurements, and remote sensing in North America. Curr. Pollut. Rep. 2015, 1, 95-116. [CrossRef]

10. Felix, J.D.; Elliott, E.M.; Gay, D.A. Spatial and temporal patterns of nitrogen isotopic composition of ammonia at U.S. ammonia monitoring network sites. Atmos. Environ. 2017, 150, 434-442. [CrossRef]

11. Liu, M.; Huang, X.; Song, Y.; Tang, J.; Cao, J.; Zhang, X.; Zhang, Q.; Wang, S.; Xu, T.; Kang, L.; et al. Ammonia emission control in China would mitigate haze pollution and nitrogen deposition, but worsen acid rain. Proc. Natl. Acad. Sci. USA 2019, 116, 7760. [CrossRef] [PubMed]

12. Pan, Y.; Gu, M.; He, Y.; Wu, D.; Liu, C.; Song, L.; Tian, S.; Lü, X.; Sun, Y.; Song, T.; et al. Revisiting the concentration observations and source apportionment of atmospheric ammonia. Adv. Atmos. Sci. 2020, 37, 933-938. [CrossRef]

13. Kong, L.; Tang, X.; Zhu, J.; Wang, Z.; Pan, Y.; Wu, H.; Wu, L.; Wu, Q.; He, Y.; Tian, S.; et al. Improved inversion of monthly ammonia emissions in China based on the Chinese ammonia monitoring network and ensemble kalman filter. Environ. Sci. Technol. 2019, 53, 12529-12538. [CrossRef] [PubMed]

14. Kang, Y.; Liu, M.; Song, Y.; Huang, X.; Yao, H.; Cai, X.; Zhang, H.; Kang, L.; Liu, X.; Yan, X.; et al. High-resolution ammonia emissions inventories in China from 1980 to 2012. Atmos. Chem. Phys. 2016, 16, 2043-2058. [CrossRef]

15. Ozgen, S.; Cernuschi, S.; Caserini, S. An overview of nitrogen oxides emissions from biomass combustion for domestic heat production. Renew. Sustain. Energy Rev. 2021, 135, 110113. [CrossRef]

16. Whitburn, S.; Van Damme, M.; Clarisse, L.; Turquety, S.; Clerbaux, C.; Coheur, P.-F. Doubling of annual ammonia emissions from the peat fires in Indonesia during the $2015 \mathrm{El}$ Niño. Geophys. Res. Lett. 2016, 43, 11007-11014. [CrossRef]

17. R'Honi, Y.; Clarisse, L.; Clerbaux, C.; Hurtmans, D.; Duflot, V.; Turquety, S.; Ngadi, Y.; Coheur, P.F. Exceptional emissions of NH 3 and HCOOH in the 2010 Russian wildfires. Atmos. Chem. Phys. 2013, 13, 4171-4181. [CrossRef]

18. Jain, N.; Bhatia, A.; Pathak, H. Emission of air pollutants from crop residue burning in India. Aerosol Air Qual. Res. 2014, 14, 422-430. [CrossRef]

19. Pan, Y.; Tian, S.; Liu, D.; Fang, Y.; Zhu, X.; Gao, M.; Gao, J.; Michalski, G.; Wang, Y. Isotopic evidence for enhanced fossil fuel sources of aerosol ammonium in the urban atmosphere. Environ. Pollut. 2018, 238, 942-947. [CrossRef]

20. Pan, Y.; Tian, S.; Liu, D.; Fang, Y.; Zhu, X.; Gao, M.; Wentworth, G.R.; Michalski, G.; Huang, X.; Wang, Y. Source apportionment of aerosol ammonium in an ammonia-rich atmosphere: An isotopic study of summer clean and hazy days in urban Beijing. J. Geophys. Res. 2018, 123, 5681-5689. [CrossRef]

21. Gu, M.; Pan, Y.; Walters, W.W.; Sun, Q.; Song, L.; Wang, Y.; Xue, Y.; Fang, Y. Vehicular emissions enhanced ammonia concentrations in winter mornings: Insights from diurnal nitrogen isotopic signatures. Environ. Sci. Technol. 2022. [CrossRef]

22. Meng, W.; Zhong, Q.; Yun, X.; Zhu, X.; Huang, T.; Shen, H.; Chen, Y.; Chen, H.; Zhou, F.; Liu, J.; et al. Improvement of a global high-resolution ammonia emission inventory for combustion and industrial sources with mew data from the residential and transportation sectors. Environ. Sci. Technol. 2017, 51, 2821-2829. [CrossRef] [PubMed] 
23. Chang, Y.; Zhu, Z.; Bu, R.; Li, Y.; Hu, Y. Environmental controls on the characteristics of mean number of forest fires and mean forest area burned (1987-2007) in China. For. Ecol. Manag. 2015, 356, 13-21. [CrossRef]

24. Xiong, Q.; Luo, X.; Liang, P.; Xiao, Y.; Xiao, Q.; Sun, H.; Pan, K.; Wang, L.; Li, L.; Pang, X. Fire from policy, human interventions, or biophysical factors? Temporal-spatial patterns of forest fire in southwestern China. For. Ecol. Manag. 2020, 474, 118381. [CrossRef]

25. Zhang, X.; Wu, Y.; Liu, X.; Reis, S.; Jin, J.; Dragosits, U.; Van Damme, M.; Clarisse, L.; Whitburn, S.; Coheur, P.-F.; et al. Ammonia emissions may be substantially underestimated in China. Environ. Sci. Technol. 2017, 51, 12089-12096. [CrossRef]

26. Pan, Y.; Tian, S.; Zhao, Y.; Zhang, L.; Zhu, X.; Gao, J.; Huang, W.; Zhou, Y.; Song, Y.; Zhang, Q.; et al. Identifying ammonia hotspots in China using a national observation network. Environ. Sci. Technol. 2018, 52, 3926-3934. [CrossRef]

27. Sun, Y.; Lei, L.; Zhou, W.; Chen, C.; He, Y.; Sun, J.; Li, Z.; Xu, W.; Wang, Q.; Ji, D.; et al. A chemical cocktail during the COVID-19 outbreak in Beijing, China: Insights from six-year aerosol particle composition measurements during the Chinese New Year holiday. Sci. Total Environ. 2020, 742, 140739. [CrossRef] [PubMed]

28. Li, J.; Wu, Y.; Ren, L.; Wang, W.; Tao, J.; Gao, Y.; Li, G.; Yang, X.; Han, Z.; Zhang, R. Variation in PM 2.5 sources in central North China Plain during 2017-2019: Response to mitigation strategies. J. Environ. Manag. 2021, 288, 112370. [CrossRef]

29. Wang, Y.; Zhang, Q.Q.; He, K.; Zhang, Q.; Chai, L. Sulfate-nitrate-ammonium aerosols over China: Response to 2000-2015 emission changes of sulfur dioxide, nitrogen oxides, and ammonia. Atmos. Chem. Phys. 2013, 13, 2635-2652. [CrossRef]

30. Xu, Z.; Liu, M.; Zhang, M.; Song, Y.; Wang, S.; Zhang, L.; Xu, T.; Wang, T.; Yan, C.; Zhou, T.; et al. High efficiency of livestock ammonia emission controls in alleviating particulate nitrate during a severe winter haze episode in northern China. Atmos. Chem. Phys. 2019, 19, 5605-5613. [CrossRef]

31. Berden, G.; Peeters, R.; Meijer, G. Cavity ring-down spectroscopy: Experimental schemes and applications. Int. Rev. Phys. Chem. 2000, 19, 565-607. [CrossRef]

32. von Bobrutzki, K.; Braban, C.F.; Famulari, D.; Jones, S.K.; Blackall, T.; Smith, T.E.L.; Blom, M.; Coe, H.; Gallagher, M.; Ghalaieny, M.; et al. Field inter-comparison of eleven atmospheric ammonia measurement techniques. Atmos. Meas. Tech. 2010, 3, 91-112. [CrossRef]

33. Martin, N.A.; Ferracci, V.; Cassidy, N.; Hoffnagle, J.A. The application of a cavity ring-down spectrometer to measurements of ambient ammonia using traceable primary standard gas mixtures. Appl. Phys. B 2016, 122, 219. [CrossRef]

34. He, Y.; Pan, Y.; Zhang, G.; Ji, D.; Tian, S.; Xu, X.; Zhang, R.; Wang, Y. Tracking ammonia morning peak, sources and transport with $1 \mathrm{~Hz}$ measurements at a rural site in North China Plain. Atmos. Environ. 2020, 235, 117630. [CrossRef]

35. Jia, Y.; Rahn, K.A.; He, K.; Wen, T.; Wang, Y. A novel technique for quantifying the regional component of urban aerosol solely from its sawtooth cycles. J. Geophys. Res. 2008, 113, D21309. [CrossRef]

36. Pu, W.; Ma, Z.; Collett, J.L., Jr.; Guo, H.; Lin, W.; Cheng, Y.; Quan, W.; Li, Y.; Dong, F.; He, D. Regional transport and urban emissions are important ammonia contributors in Beijing, China. Environ. Pollut. 2020, 265, 115062. [CrossRef] [PubMed]

37. Saraswati; Sharma, S.K.; Mandal, T.K. Five-year measurements of ambient ammonia and its relationships with other trace gases at an urban site of Delhi, India. Meteorol. Atmos. Phys. 2018, 130, 241-257. [CrossRef]

38. Backes, A.; Aulinger, A.; Bieser, J.; Matthias, V.; Quante, M. Ammonia emissions in Europe, part I: Development of a dynamical ammonia emission inventory. Atmos. Environ. 2016, 131, 55-66. [CrossRef]

39. He, Y.; Pan, Y.; Gu, M.; Sun, Q.; Zhang, Q.; Zhang, R.; Wang, Y. Changes of ammonia concentrations in wintertime on the North China Plain from 2018 to 2020. Atmos. Res. 2021, 253, 105490. [CrossRef]

40. Li, Y.; Liu, J.; Han, H.; Zhao, T.; Zhang, X.; Zhuang, B.; Wang, T.; Chen, H.; Wu, Y.; Li, M. Collective impacts of biomass burning and synoptic weather on surface $\mathrm{PM}_{2.5}$ and $\mathrm{CO}$ in Northeast China. Atmos. Environ. 2019, 213, 64-80. [CrossRef]

41. Whitburn, S.; Van Damme, M.; Clarisse, L.; Hurtmans, D.; Clerbaux, C.; Coheur, P.F. IASI-derived $\mathrm{NH}_{3}$ enhancement ratios relative to $\mathrm{CO}$ for the tropical biomass burning regions. Atmos. Chem. Phys. 2017, 17, 12239-12252. [CrossRef]

42. Andreae, M.O.; Merlet, P. Emission of trace gases and aerosols from biomass burning. Glob. Biogeochem. Cycles 2001, 15, 955-966. [CrossRef]

43. Song, L.; Walters, W.W.; Pan, Y.; Li, Z.; Gu, M.; Duan, Y.; Lü, X.; Fang, Y. ${ }^{15} \mathrm{~N}$ natural abundance of vehicular exhaust ammonia, quantified by active sampling techniques. Atmos. Environ. 2021, 255, 118430. [CrossRef]

44. Hegg, D.A.; Radke, L.F.; Hobbs, P.V.; Riggan, P.J. Ammonia emissions from biomass burning. Geophys. Res. Lett. 1988, 15, 335-337. [CrossRef]

45. Yokelson, R.J.; Crounse, J.D.; DeCarlo, P.F.; Karl, T.; Urbanski, S.; Atlas, E.; Campos, T.; Shinozuka, Y.; Kapustin, V.; Clarke, A.D.; et al. Emissions from biomass burning in the Yucatan. Atmos. Chem. Phys. 2009, 9, 5785-5812. [CrossRef]

46. Akagi, S.K.; Craven, J.S.; Taylor, J.W.; McMeeking, G.R.; Yokelson, R.J.; Burling, I.R.; Urbanski, S.P.; Wold, C.E.; Seinfeld, J.H.; Coe, H.; et al. Evolution of trace gases and particles emitted by a chaparral fire in California. Atmos. Chem. Phys. 2012, 12, 1397-1421. [CrossRef]

47. Benedict, K.B.; Prenni, A.J.; Carrico, C.M.; Sullivan, A.P.; Schichtel, B.A.; Collett, J.L. Enhanced concentrations of reactive nitrogen species in wildfire smoke. Atmos. Environ. 2017, 148, 8-15. [CrossRef]

48. Baker, K.; Koplitz, S.; Foley, K.; Avey, L.; Hawkins, A. Characterizing grassland fire activity in the Flint Hills region and air quality using satellite and routine surface monitor data. Sci. Total Environ. 2019, 659, 1555-1566. [CrossRef] [PubMed]

49. Lindaas, J.; Pollack, I.B.; Calahorrano, J.J.; O’Dell, K.; Garofalo, L.A.; Pothier, M.A.; Farmer, D.K.; Kreidenweis, S.M.; Campos, T.; Flocke, F.; et al. Empirical insights into the fate of ammonia in western U.S. Wildfire smoke plumes. J. Geophys. Res. 2021, 126, e2020JD033730. [CrossRef] 